\title{
EFFECT OF ETHYLENE INHIBITORS ON QUALITY ATTRIBUTES OF APRICOT CV. MODESTO AND PATTERSON DURING STORAGE
}

\author{
Héctor Valdés ${ }^{1}$, Melissa Pizarro², Reinaldo Campos-Vargas ${ }^{1,3}$, Rodrigo Infante ${ }^{2}$, and Bruno G. \\ Defilippi ${ }^{1,3 *}$
}

\begin{abstract}
Apricot (Prunus armeniaca L.) fruit are highly susceptible to flesh softening, loss of flavor and fruit decay, particularly during postharvest storage. Most of these quality changes observed during fruit ripening are under ethylene regulation. We performed a study with the objective of determining the effect of 1-methylcyclopropene (1-MCP) and aminoethoxyvinylglycine (AVG) applications on quality attributes of Modesto and Patterson apricot cultivars. 1-MCP was applied at a rate of 1000 and $10000 \mathrm{~nL} \mathrm{~L}^{-1}$ of SmartFresh ${ }^{\mathrm{TM}}$, and AVG at a rate 100 and 1000 $\mathrm{mg} \mathrm{L}^{-1}$ of Retain ${ }^{\circledR}$. Quality evaluations were performed after 20 and 30 days of cold storage and after a shelf-life period of 3-4 days at $20^{\circ} \mathrm{C}$. In general, both ethylene inhibitors were effective in reducing the ethylene production rate, especially in Patterson. Fruit softening and color development showed ethylene-dependent behavior, with significant reductions for both varieties in fruit treated with 1-MCP and AVG. On the other hand, soluble solids concentration and titratable acidity showed an ethylene-independent pattern, i.e. they were not affected by ethylene inhibitors applications. Among volatile compounds identified, esters and aldehydes showed ethylene-dependent behavior in both varieties. On the other hand, alcohols and terpenes were not affected by ethylene inhibition, suggesting ethylene-independent behavior.
\end{abstract}

Key words: ripening, quality, 1-methylcyclopropene, aminoethoxyvinylglycine, Prunus armeniaca, aroma.

\section{INTRODUCTION}

The apricot (Prunus armeniaca L.) is a climacteric fruit and its physiological state at harvest strongly influences the evolution of the maturation process (Chahine et al., 1999; Infante et al., 2008). If apricots are harvested too early they do not reach an optimum quality given that texture, sweetness, acidity and aroma do not develop normally (Chahine et al., 1999; Manolopoulou and Mallidis, 1999). Likewise, a late harvest results in a rapid deterioration of the fruit (Manolopoulou and Mallidis, 1999). A serious problem in marketing apricots is their excessive softening, with a correlation between ethylene emissions and the firmness of the fruit (Chahine et al., 1999; Botondi et al., 2003).

\footnotetext{
${ }^{1}$ Instituto de Investigaciones Agropecuarias, Centro Regional de Investigación La Platina, Santa Rosa 11610, La Pintana, Santiago, Chile. "Corresponding author (bdefilip@inia.cl).

${ }^{2}$ Universidad de Chile, Facultad de Ciencias Agronómicas, Casilla 1004, Santiago, Chile.

${ }^{3}$ Núcleo Milenio en Biotecnología Celular Vegetal.

Received: 08 May 2008.

Accepted: 19 June 2008.
}

The composition of flavor has been defined as a complex quality attribute, in which the balance of sugars, acids and volatiles play primary roles (Baldwin, 2002). During the development of the fruit, many of the changes in flavor are caused by synthesis, transport or degradation of metabolites. The content of sugars, organic acids and volatile compounds, as well as color, shape and texture, determine the sensorial properties of the fruit (Azondanlou et al., 2003). An important sensorial attribute is flavor, with a direct effect on consumer acceptance and is determined mainly by chemical sensations like smell and taste (Baldwin, 2002). The typical flavor of the majority of the fruits is not present during their first developmental states but rather develops during the maturation process (Pérez et al., 1992). All of these qualities of the fruit can be directly regulated by ethylene or by other signals (Bauchot et al., 1998; Defilippi et al., 2004).

Ethylene is critical in the maturation process and is involved in many changes that occur in the fruit, such as the degradation of chlorophyll, softening, respiration and the production of volatiles (Abeles et al., 1992; Abdi et al., 1998; Palou et al., 2003). Different strategies have been used to study the effects of ethylene on the fruit, including the use of chemical inhibitors and biotechnological tools (Defilippi et al., 2004). 
Notable among the chemical inhibitors, because of their commercial importance, are aminoethoxyvinylglycine (AVG) and 1-methylcyclopropene (1-MCP). 1-MCP is a synthetic cyclopropene that blocks ethylene receptors for extended periods of time and impedes the physiological effects on plant tissue that are induced by ethylene. It has been demonstrated that 1-MCP inhibits the maturation of fruit and improves quality after storage of climacteric fruit, such as apples (Malus domestica Borkh.) (Abdi et al., 1998), plum (Prunus salicina Lindl.) (Blankenship and Dole, 2003) and avocado (Persea americana Mill.) (Watkins, 2006). The use of 1-MCP with apricots, in doses of 0.5 to $1.5 \mu \mathrm{L} \mathrm{L}^{-1}$, has been restricted to the experimental level and has proven to have an effect in delaying the beginning of the climacteric rise of the ethylene and respiratory rate. This effect has been sufficient to extend storage, slowing the loss of firmness and titratable acidity, as well as color changes associated with maturation (Fan et al., 2000; Botondi et al., 2003; De Martino et al., 2006).

Aminoethoxyvinylglycine (AVG) inhibits the synthesis of ethylene at the level of the aminocyclopropane carboxylic acid synthase enzyme (ACS), responsible for the conversion of S-adenosylmetionine to 1-aminocyclopropane 1-carboxylic acid (ACC), the latter an immediate precursor of ethylene (Adams and Yang, 1979). ACC synthase is considered a key enzyme in the biosynthesis of ethylene (Kende, 1993). AVG is the active ingredient in the commercial product Retain ${ }^{\circledR}$, and its commercial use has been focused mainly on aspects of pre-harvest fruit management, such as reducing fruit fall and slowing the development of parameters of maturity attributes in apples (Byers, 1997). Pre-harvest application of AVG in stone fruit has had a significant effect in reducing ethylene production and softening rate of the fruit (Bregoli et al., 2002; Jobling et al., 2003). Similarly, apricots with postharvest application of AVG and evaluated after only 5 days at $20^{\circ} \mathrm{C}$, had a lower level of ethylene production and more firmness than those with no application, a situation that varies according to the variety being used (Palou and Crisosto, 2003).
Given the proceeding, it is evident that the information available on the use of 1-MCP and AVG with apricots is limited, especially considering the effect of the genotype and the extended storage or transport conditions to which the fruit is submitted to in order to reach distant markets. The main objective of the present research was to determine the effect of both ethylene inhibitors on the distinct components that define quality in the two apricot varieties stored for extended periods. As well, the parameters were identified that are modulated by ethylene during the maturation process.

\section{MATERIALS AND METHODS}

\section{Vegetal material and treatments}

The apricots used in the test were from of the Modesto and Patterson varieties obtained from a commercial distributor. To undertake the assay the fruit were taken to the laboratory where fruit was selected that corresponded to a state of maturity determined by greenish-yellow color of the skin in both varieties. The characterizations of the parameters of the initial evaluation are presented in Table 1.

The application of 1-MCP (SmartFresh ${ }^{\mathrm{TM}}$, AgroFresh, Philadelphia, USA) was done for $24 \mathrm{~h}$ at $0{ }^{\circ} \mathrm{C}$. Following the application, the fruit was stored in a cold chamber at $0^{\circ} \mathrm{C}$ and $95 \% \mathrm{HR}$, until the time indicated for their evaluation. AVG (Retain ${ }^{\circledR}$, Valent BioSciences, Libertyville, USA) was applied by immersion for $10 \mathrm{~min}$ at room temperature (Palou and Crisosto, 2003). Storage was conducted for 20 and 30 days in a cold chamber at $0{ }^{\circ} \mathrm{C}$, each storage period followed by its respective maturation in a chamber at 20 ${ }^{\circ} \mathrm{C}$. The treatments for the Modesto and Patterson varieties are detailed in Table 2.

\section{Ethylene production rate and respiratory rate}

Measurement of the rate of ethylene production was carried out twice, once at the end of the period of refrigerated storage and at the end of the maturation period in a chamber at $20^{\circ} \mathrm{C}$. The fruit was stored in sealed flasks at $20^{\circ} \mathrm{C}$ for a period of $3 \mathrm{~h}$ to obtained gases adequately. The sample was taken from $1 \mathrm{~mL}$ of the head space,

Table 1. Physiological and quality parameters at harvest time in Modesto and Patterson apricot cultivars.

\begin{tabular}{lrr}
\hline & \multicolumn{2}{c}{ Variety } \\
\cline { 2 - 3 } Parameter & \multicolumn{1}{c}{ Modesto } & Patterson \\
\hline Firmness, kgf & $4.3 \pm 0.2$ & $4.5 \pm 0.2$ \\
Color, Hue angle & $78.0 \pm 1.0$ & $76.3 \pm 0.6$ \\
Soluble solid content, \% & $11.3 \pm 0.4$ & $12.1 \pm 0.3$ \\
Titratable acidity, \% malic acid & $1.6 \pm 0.04$ & $1.3 \pm 0.1$ \\
Ethylene production rate, $\mu \mathrm{L} \mathrm{C}_{2} \mathrm{H}_{4} \mathrm{~kg}^{-1} \mathrm{~h}^{-1}$ measured at $20^{\circ} \mathrm{C}$ & $0.5 \pm 0.1$ & $0.2 \pm 0.1$ \\
Respiratory rate, $\mathrm{mL} \mathrm{CO}_{2} \mathrm{~kg}^{-1} \mathrm{~h}^{-1}$ measured at $20^{\circ} \mathrm{C}$ & $30.1 \pm 0.7$ & $28.0 \pm 0.6$ \\
\hline
\end{tabular}


Table 2. Experimental treatments applied in Modesto and Patterson apricot cultivars.

\begin{tabular}{cl}
\hline Treatments & \multicolumn{1}{c}{ Description } \\
\hline $\mathrm{T} 1$ & Control, without application \\
$\mathrm{T} 2$ & $1000 \mathrm{~nL} \mathrm{~L}^{-1} 1-\mathrm{MCP}^{1}\left(\right.$ SmartFresh $\left.^{\mathrm{TM}}\right)$ \\
$\mathrm{T} 3$ & $10000 \mathrm{~nL} \mathrm{~L}^{-1} 1-\mathrm{MCP}\left(\right.$ SmartFresh $\left.^{\mathrm{TM}}\right)$ \\
$\mathrm{T} 4$ & $100 \mathrm{mg} \mathrm{L}^{-1} \mathrm{AVG}^{2}\left(\right.$ Retain $\left.{ }^{\circledR} 15 \% \mathrm{p} / \mathrm{p}\right)$ \\
$\mathrm{T} 5$ & $1000 \mathrm{mg} \mathrm{L}^{-1} \mathrm{AVG}($ Retain $\AA 15 \% \mathrm{p} / \mathrm{p})$ \\
\hline
\end{tabular}

${ }^{1} 1$-MCP (1-methylcyclopropene). ${ }^{2} \mathrm{AVG}$ (aminoethoxyvinylglycine).

which was injected into a gas chromatograph (Shimadzu, GC 8A, Tokyo, Japan) with aluminum column and flame ionization detector (FID). The results were expressed in $\mu \mathrm{L} \mathrm{C}_{2} \mathrm{H}_{4} \mathrm{~kg}^{-1} \mathrm{~h}^{-1}$. Measurement of the respiratory rate was conducted with the same fruits used for measuring ethylene. Measurement of the gases was made using an oxygen and carbon dioxide meter (PBI-Dansensor, Checkmate 9900, Ringsted, Denmark). The results were expressed in $\mathrm{mL} \mathrm{CO}_{2} \mathrm{~kg}^{-1} \mathrm{~h}^{-1}$. Five replicates were made of both measurements of each fruit.

\section{Quality and maturity parameters}

Pulp firmness was measured using a manual penetrometer (Fruti Tester, Effegi, Milan, Italy) with a plunger $7.9 \mathrm{~mm}$ in diameter. The measurement was made on the two cheeks of the fruit after removing the skin. The results are expressed in kgf. The soluble solid content (SSC) was measured with a manual temperaturecompensated refractometer (ATC-1E, Atago, Tokyo, Japan) in a sample of juice from the pulp of each fruit, with the results expressed in percentages. Both evaluations were made with 15 fruits per treatment. Titratable acidity was obtained through the titulation of $10 \mathrm{~mL}$ of juice from a representative sample of the fruits, con $\mathrm{NaOH} 0.1$ $\mathrm{N}$ until achieving the neutralization of the organic acids to $\mathrm{pH}$ 8.2-8.3. In this case, three samples composed of five fruit each were used for treatment and the results were expressed as a percentage of malic acid (Dong et al., 2002). To measure the color, a portable tri-stimulus colorimeter (CR-300, Minolta, Tokyo, Japan) was used, employing the CIELab system (Egea et al., 2007). To measure the change from green to yellow, the tonality value was used (Hue angle), which was obtained through the equation Hue $=\tan ^{-1}\left(b^{*} / a^{*}\right)$.

\section{Determination of volatiles responsible for aroma}

To determine the aromatic profile of both varieties of apricots, pattern curves were made of the compounds belonging to the chemical groups of aldehydes, esters, alcohols, terpenes and lactones. The treatments that were used in this measurement were $\mathrm{T} 1, \mathrm{~T} 3$ and $\mathrm{T} 5$, which correspond to the control, $10000 \mathrm{~nL} \mathrm{~L}^{-1} 1-\mathrm{MCP}$ (SmartFresh ${ }^{\mathrm{TM}}$ ) and $1000 \mathrm{mg} \mathrm{L}^{-1}$ AVG (Retain ${ }^{\circledR}$ 15\% $\mathrm{p} / \mathrm{p})$ respectively. Six grams of tissue were taken and homogenized in a tritulator (T-25, Ultra-Turrax, Staufen, Germany) containing $12 \mathrm{~mL}$ of water and $\mathrm{NaF} 2 \mathrm{mM}$. It was then filtered and centrifuged at $20000 \mathrm{~g}$ for $20 \mathrm{~min}$ at 4 ${ }^{\circ} \mathrm{C}$. Some $10 \mathrm{~mL}$ of the supernatant was mixed with $20 \mathrm{~mL}$ of solution of $\mathrm{NaCl} 10 \% \mathrm{p} / \mathrm{v}$ (Shalit et al., 2001). Before sealing the flasks, $0.78 \mu \mathrm{L}$ of internal standard 1-octanol was added to obtain $250 \mu \mathrm{L} \mathrm{L}^{-1}$ of final concentration. To extract the sample from the head space, the solid phase microextraction (SPME) system was used, with a polyfiber of polydimethylsiloxane/divinylbenzene (PDMS/ DVB) of $65 \mu \mathrm{m}$ of thickness (Defilippi et al., 2004). The quantification of the compounds was done using a gas (Clarus 500, Perkin Elmer, Shelton, USA), equipped with SPB-5 column (Supelco $30 \mathrm{~m}, 0.32 \mathrm{~mm}$ i.d., 0.25 $\mu \mathrm{m}$ thick film) and a FID detector. The oven temperature was maintained at $40{ }^{\circ} \mathrm{C}$ for $5 \mathrm{~min}$ and then increased to $220^{\circ} \mathrm{C}$ at a rate of $10{ }^{\circ} \mathrm{C}$ per minute and was maintained for 2 min (Moya-León et al., 2006). Helium was used as a carrier gas $\left(50.3 \mathrm{~cm} \mathrm{~s}^{-1}\right)$. The quantification of volatiles was conducted under conditions identical to those used in the analysis of the samples.

\section{RESULTS AND DISCUSSION}

\section{Characterization of the fruit at harvest}

As mentioned before, the fruit was harvested with a greenish-yellow color, which is reflected in measurements of the colorimeter with Hue values above 75 in both varieties (Table 2). The ethylene production rate of ethylene of 'Modesto' and 'Patterson' was quite low, fluctuating between 0.5 and $0.2 \mu \mathrm{L} \mathrm{C}_{2} \mathrm{H}_{4} \mathrm{~kg}^{-1} \mathrm{~h}^{-1}$ respectively, with that of 'Modesto' being slightly higher. This level of measured ethylene would indicate that both varieties are in incipient states of maturation (pre-climacteric) (Botondi et al., 2003). As well, the high values of pulp firmness and acidity are characteristic of apricots in early stages of maturation for both varieties (Gómez and Ledbetter, 1997; Aubert and Chanforan, 2007).

\section{Characterization of the fruit during refrigerated storage}

Respiratory and ethylene rates. The ethylene production rates of 'Modesto' showed significant differences among treatments in fruit at ripening after 20 days of storage at $0{ }^{\circ} \mathrm{C}$ plus 4 days at $20^{\circ} \mathrm{C}$, with the control having the highest value (Figure 1). The fruit treated with 1-MCP and AVG showed evidence of inhibition of ethylene production equal to or greater than $75 \%$ in comparison to the control, a situation described previously with other varieties of apricots (Fan et al., 2000; 
Dong et al., 2002). After 30 days of storage at $0{ }^{\circ} \mathrm{C}$, both treatments with $\mathrm{AVG}$ had the lowest production values. However, these differences disappeared once ripening is reached. With the 'Patterson' apricots maintained for 20 days in storage at $0^{\circ} \mathrm{C}$, the control treatment presented the highest ethylene production rate, of $0.5 \mu \mathrm{L} \mathrm{C} \mathrm{C}_{2} \mathrm{Hg}^{-1} \mathrm{~h}^{-1}$, compared to the fruit treated with 1-MCP or AVG for both doses applied (Figure 2). Of these treatments, the lowest ethylene production rate was observed in the fruit treated with AVG, where the response was independent of the doses used. The prolonged inhibiting effect of AVG on ethylene production in 'Patterson' is interesting, especially given that it inhibits synthesis and not perception, which would not avoid activating ethylene biosynthesis by the presence of exogenous ethylene. In terms of the respiratory rate, no important effect was observed on any of the treatments evaluated of either variety (data not shown).

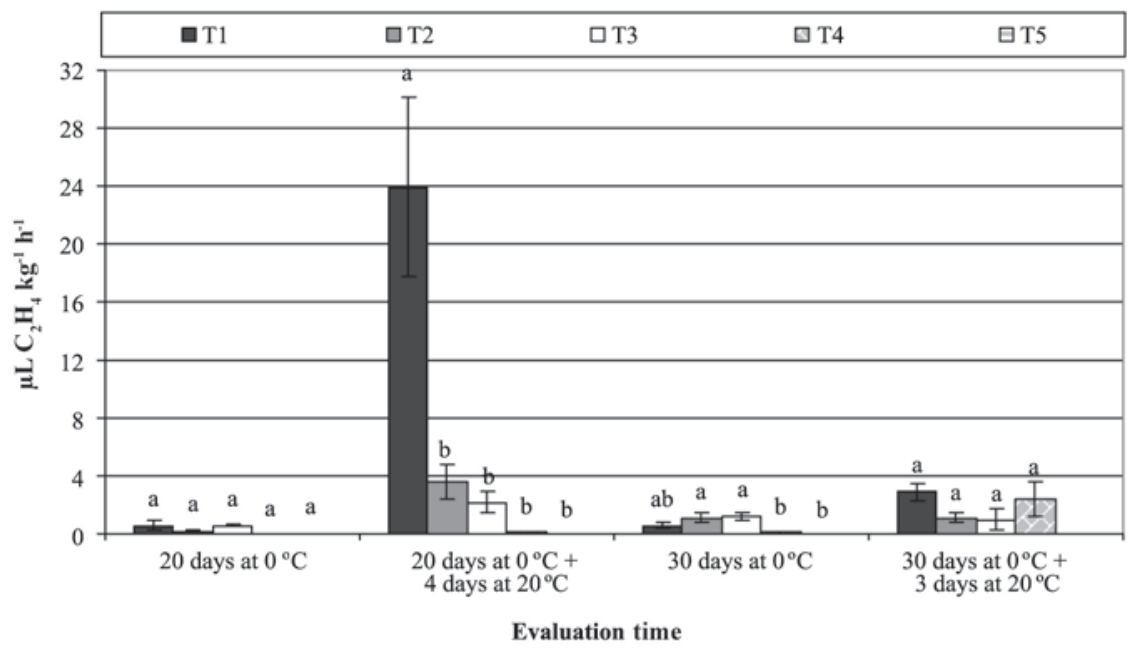

(T1) Control, (T2) $1000 \mathrm{~nL} \mathrm{~L}^{-1}$ 1-MCP (1-methylcyclopropene), (T3) $10000 \mathrm{~nL} \mathrm{~L}^{-1}$ 1-MCP (1-methylcyclopropene), (T4) $100 \mathrm{mg} \mathrm{L}^{-1}$ AVG (aminoethoxyvinylglycine), (T5) $1000 \mathrm{mg} \mathrm{L}^{-1} \mathrm{AVG}$ (aminoethoxyvinylglycine).

Figure 1. Ethylene production rate in 'Modesto' apricots after 20 and 30 days of cold storage at $0{ }^{\circ} \mathrm{C}$, and after a period at $20^{\circ} \mathrm{C}$ to reach ripening.

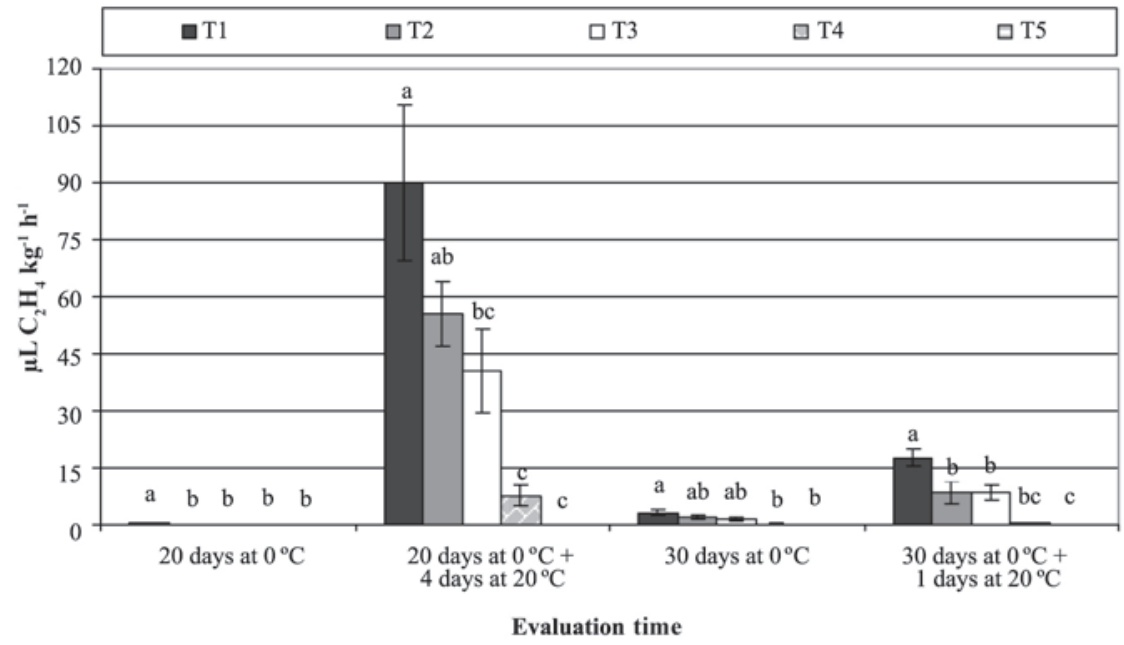

(T1) Control, (T2) $1000 \mathrm{~nL} \mathrm{~L}^{-1}$ 1-MCP (1-methylcyclopropene), (T3) $10000 \mathrm{~nL} \mathrm{~L}^{-1}$ 1-MCP (1-methylcyclopropene), (T4) $100 \mathrm{mg} \mathrm{L}^{-1}$ AVG (aminoethoxyvinylglycine), (T5) $1000 \mathrm{mg} \mathrm{L}^{-1} \mathrm{AVG}$ (aminoethoxyvinylglycine).

Figure 2. Ethylene production rate in 'Patterson' apricots after 20 and 30 days of cold storage at $0{ }^{\circ} \mathrm{C}$, and after a period at $20^{\circ} \mathrm{C}$ to reach ripening. 
Quality and maturity parameter. As expected, the firmness values of both varieties decreased with the advance of the maturation process, both through increasing the storage period and exposing the fruit to maturation at $20{ }^{\circ} \mathrm{C}$ (Figures 3 and 4). In general for 'Modesto' no major differences were observed after 20 days of storage. However, after maturation the control treatment showed less firmness than the other treatments, while the fruit applied with AVG had the lowest rate of ethylene production (Figure 3). After extending the storage period to 30 days, no differences were observed between treated fruits and the control, both upon removing them cold storage and after maturation, a situation that is directly related to limited or non-existent effect of AVG or 1-MCP in affecting the synthesis of ethylene. In the case of 'Patterson', after 20 days of storage, the treatment with the highest doses of 1-MCP presented the highest firmness compared to the other treatments (Figure 4).

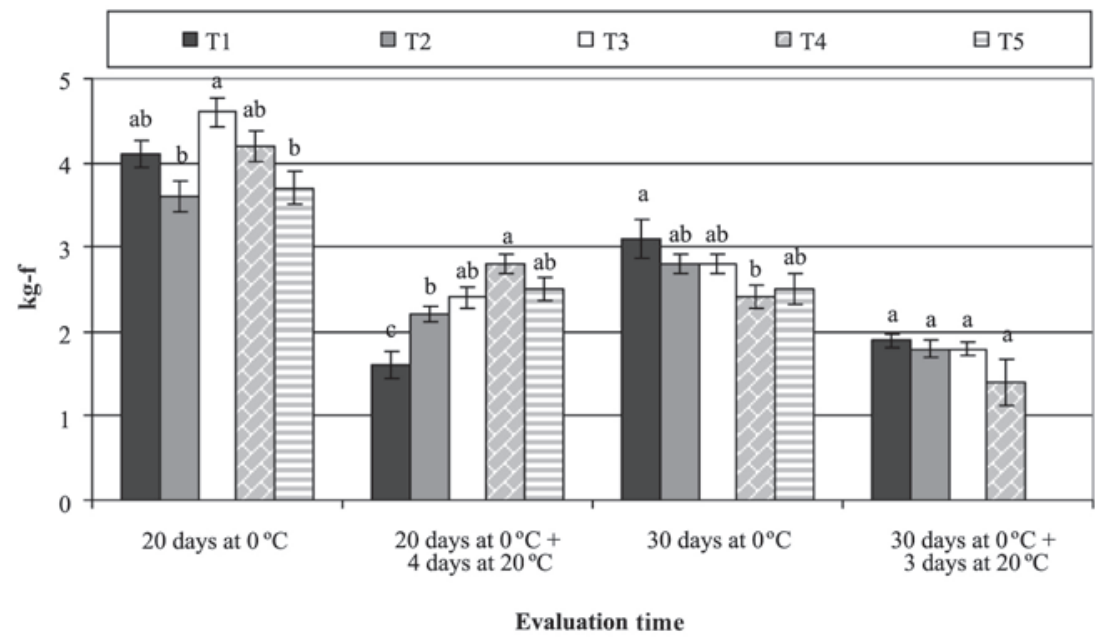

(T1) Control, (T2) $1000 \mathrm{~nL} \mathrm{~L}^{-1}$ 1-MCP (1-methylcyclopropene), (T3) $10000 \mathrm{~nL} \mathrm{~L}^{-1}$ 1-MCP (1-methylcyclopropene), (T4) $100 \mathrm{mg} \mathrm{L}^{-1} \mathrm{AVG}$ (aminoethoxyvinylglycine), (T5) $1000 \mathrm{mg} \mathrm{L}^{-1} \mathrm{AVG}$ (aminoethoxyvinylglycine).

Figure 3. Firmness in 'Modesto' apricots after 20 and 30 days of cold storage at $0{ }^{\circ} \mathrm{C}$, and after a period at $20{ }^{\circ} \mathrm{C}$ to reach ripening.

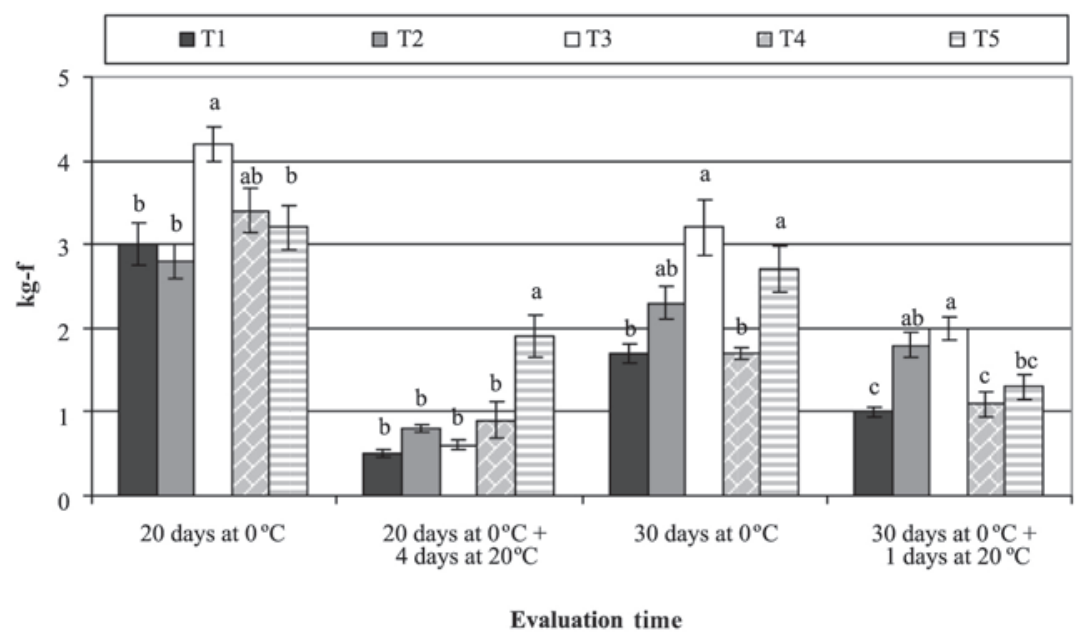

(T1) Control, (T2) $1000 \mathrm{~nL} \mathrm{~L}^{-1}$ 1-MCP (1-methylcyclopropene), (T3) $10000 \mathrm{~nL} \mathrm{~L}^{-1}$ 1-MCP (1-methylcyclopropene), (T4) $100 \mathrm{mg} \mathrm{L}$-1 AVG (aminoethoxyvinylglycine), (T5) $1000 \mathrm{mg} \mathrm{L}^{-1} \mathrm{AVG}$ (aminoethoxyvinylglycine).

Figure 4. Firmness in 'Patterson' apricots after 20 and 30 days of cold storage at $0{ }^{\circ} \mathrm{C}$, and after a period at $20^{\circ} \mathrm{C}$ to reach ripening. 
Nevertheless, after maturation the treatment with the highest doses of AVG presented the highest firmness, exceeding the other treatments by more than $2 \mathrm{kgf}$. A similar situation was observed in peaches and nectarines treated with $\mathrm{AVG}$ in postharvest by immersion in doses of between 167 and $10000 \mathrm{mg} \mathrm{L}^{-1}$ where the softening rate of the fruit was significantly slowed (Byers, 1997). At 30 days of storage, the treatments with the highest dose were the most effective in maintaining the firmness of the fruit for both products. In contrast, upon ripening, the highest firmness was presented solely by fruits treated with 1MCP. The effect of both inhibitors is mainly because ethylene modulates the activity of a complex of enzymes involved in the softening process. Nevertheless, the level of modulation is dependent on the species and the variety studied (Mbéguié-Mbéguié et al., 2002; Botondi et al., 2003; Palou et al., 2003).

In relation to color, a change was observed from greenish yellow to reddish yellow during the storage period (Figures 5 and 6). The differences were found with 'Modesto' after 20 days of storage at $0{ }^{\circ} \mathrm{C}$, where the highest doses of both products showed the highest Hue values, that is to say, coloration that tended to green that characteristic of fruit in less advanced stages of maturation (Figure 5). Nevertheless, after maturation only the treatments with AVG presented the highest values, which

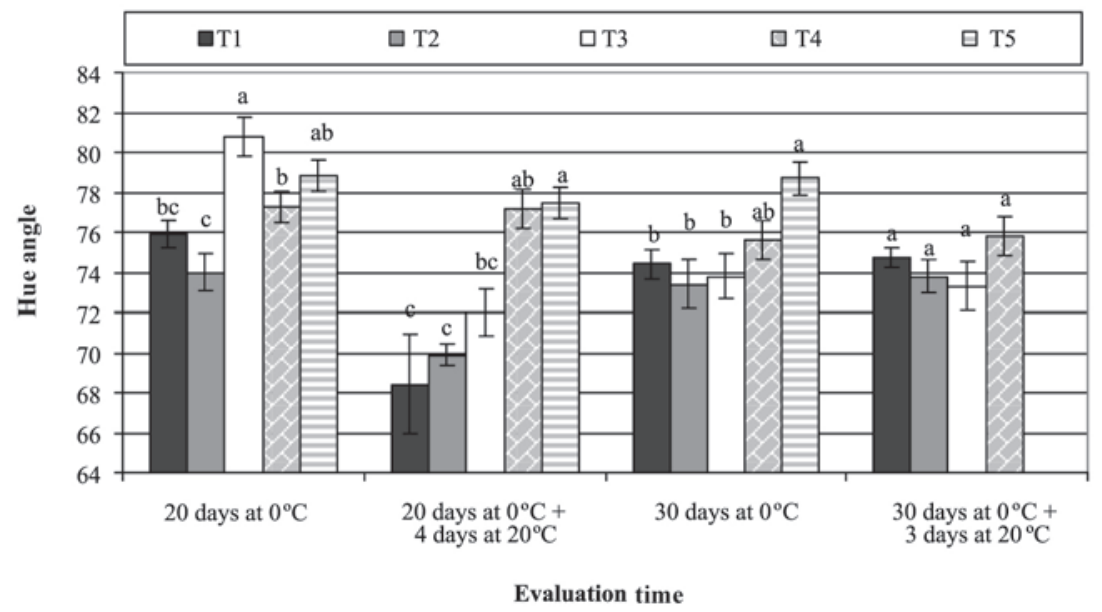

(T1) Control, (T2) $1000 \mathrm{~nL} \mathrm{~L}^{-1}$ 1-MCP (1-methylcyclopropene), (T3) $10000 \mathrm{~nL} \mathrm{~L}^{-1}$ 1-MCP (1-methylcyclopropene), (T4) $100 \mathrm{mg} \mathrm{L} \mathrm{AVG}^{-1} \mathrm{AVGinoe-}$ thoxyvinylglycine), (T5) $1000 \mathrm{mg} \mathrm{L}^{-1} \mathrm{AVG}$ (aminoethoxyvinylglycine).

Figure 5. Color development in 'Modesto' apricots after 20 and 30 days of cold storage at $0{ }^{\circ} \mathrm{C}$, and after a period at 20 ${ }^{\circ} \mathrm{C}$ to reach ripening.

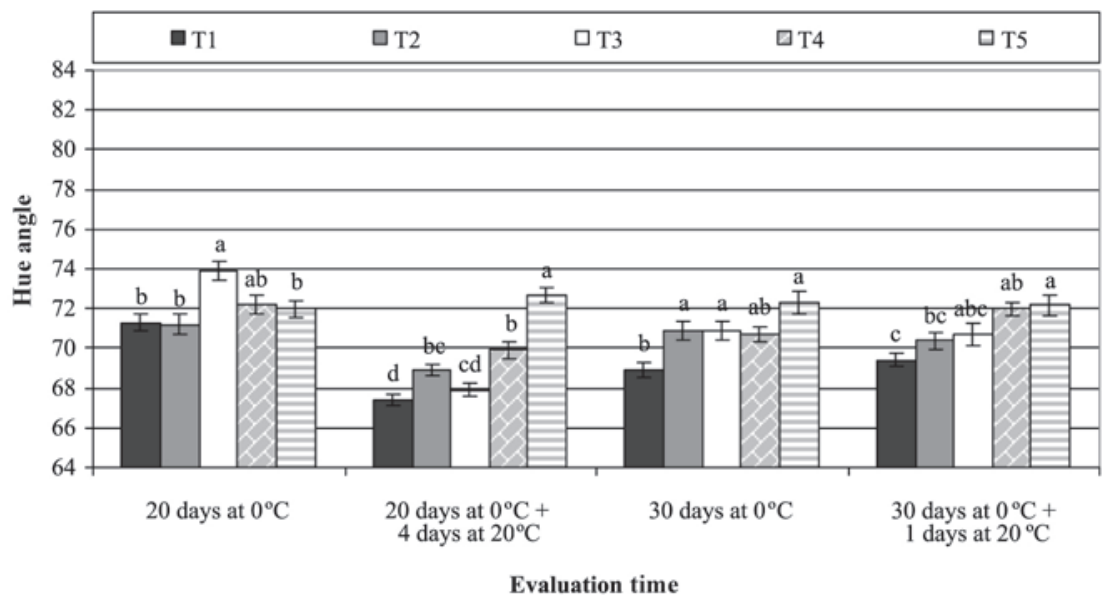

(T1) Control, (T2) $1000 \mathrm{~nL} \mathrm{~L}^{-1}$ 1-MCP (1-methylcyclopropene), (T3) $10000 \mathrm{~nL} \mathrm{~L}^{-1}$ 1-MCP (1-methylcyclopropene), (T4) $100 \mathrm{mg} \mathrm{L}^{-1} \mathrm{AVG}$ (aminoethoxyvinylglycine), (T5) $1000 \mathrm{mg} \mathrm{L}^{-1} \mathrm{AVG}$ (aminoethoxyvinylglycine).

Figure 6. Color development in 'Patterson' apricots after 20 and 30 days of cold storage at $0{ }^{\circ} \mathrm{C}$, and after a period at 20 ${ }^{\circ} \mathrm{C}$ to reach ripening. 
coincides with the higher levels of ethylene inhibition observed in fruit treated with AVG. At 30 days of storage, the fruit treated with the highest doses of AVG showed greener colors than the other treatments, a situation that changes after maturation of fruit with a similar rate of ethylene production. In the case of 'Patterson', after 20 days of storage, the highest Hue value was observed in the fruit treated with the highest doses of 1-MCP (Figure 6). On the other hand, upon maturation at $20^{\circ} \mathrm{C}$, the fruits treated with the highest dose of AVG maintained a greener shade than the other treatments. After 30 days of storage at $0{ }^{\circ} \mathrm{C}$, independent of the product that had been applied, higher values of Hue were observed in the treatments with application in comparison to the control, similar situation occurred in fruit that ripened after 30 days of storage. The dependence of the color variable on ethylene has been reported in other species such as tomatoes, melons and apples (Wang and Dilley, 2001; Defilippi et al., 2004), where in the case of apricots, the available information suggests a modulating effect on the biosynthesis of carotenoids (Marty et al., 2005; Dragovic-Uzelac et al., 2007).

No differences were observed in the measurements of acidity among the treatments, except for the Patterson variety at ripening after 20 days of storage, where the highest levels corresponded to fruit applied with the highest dose of 1-MCP (data not shown). Consequently, the metabolism of the acids in apricots is independent of ethylene (Chahine et al., 1999; Cardarelli et al., 2002). In a similar manner, the results of soluble solid content did not allow for establishing a determined behavior on the effect of the different treatments on this measurement, with no differences between the fruit treated with ethylene inhibitors and those that were untreated, because of which it is possible to establish the independence of this parameter from ethylene production (data not shown). In general it was observed that 'Patterson' had higher levels of total soluble solids than 'Modesto' upon evaluation, which is due to the genetic variability between the varieties.

\section{Determination of volatiles responsible for aroma}

The aromatic profile of apricots var. Modesto and Patterson is made up of eight volatile compounds, of which those that have a higher incidence in quantitative terms in decreasing order belong to the chemical group of aldehydes, terpenes, alcohols and esters. The most abundant aldehydes produced by the var. Modesto and Patterson were hexanal and trans-2-hexenal (Tables 3 and 4). A low production of these compounds was observed in the fruits treated with AVG in comparison to those with other treatments, specifically in fruit evaluated immediately after 20 days of refrigerated storage (Tables 3 and 4). Nevertheless, as the storage period continued there was an observable reduction in the production of these volatiles in all the treatments in both varieties compared to the evaluation at harvest (Gómez and Ledbetter, 1997; Aubert and Chanforan, 2007). In contrast to what was observed in the fruit applied with AVG, the apricots treated with 1-MCP in general had similar levels of aldehydes to those of the control, especially with extended storage of 30 days. Upon exposing the fruit for a period at $20{ }^{\circ} \mathrm{C}$ until ripening, an increase in aldehyde production was observed, with all the treatments reaching similar levels. As was described for Figures 1 and 2 , the rate of ethylene production in both varieties increased once the fruit was exposed to $20^{\circ} \mathrm{C}$. Although this increase was less pronounced in the treatments with 1-MCP or AVG, the low level of ethylene was sufficient to trigger the biosynthesis of aldehydes, indicating a low threshold of ethylene required initiating this process. These results suggest a role for ethylene in modulating the biosynthesis of aldehydes en 'Modesto' and 'Patterson', a situation already described in other varieties (Gómez and Ledbetter, 1997; Botondi et al., 2003).

The production of esters in apricots is highly variable depending on the variety and normally increases during the maturation process (Botondi et al., 2003; Aubert and Chanforan, 2007). In 'Patterson' and 'Modesto', the production of esters such as butyl butanoate and ethyl octanoate had low levels of productions throughout the evaluations periods. Despite this, a decrease was observed in the production of esters in the fruit applied with inhibitors, especially after 20 days at $0{ }^{\circ} \mathrm{C}$, similar to what was observed for aldehydes. These results suggest an effect of ethylene as a modulator of the biosynthesis of esters, a behavior already studied in other climacteric fruits such as apple (Malus domestica Borkh.), melon (Cucumis melo L.) and papaya (Vasconcellea pubescens A. DC.) (Bauchot et al., 1998; Defilippi et al., 2004; Balbontín et al., 2007). Linalool, one of the most important volatiles along with lactones as contributors to the aroma characteristic of apricots, had higher levels of production in the var. Patterson than in Modesto (Tables 3 and 4) (Greger and Schieberle, 2007). In general, the levels of production of this compound remained constant at both harvest and the two periods of refrigerated storage, independent of whether or not ethylene inhibitors were used. The only alcohol detected in both varieties was hexanol, which had an erratic behavior that did not allow for establishing the degree of dependence on ethylene.

\section{CONCLUSIONS}

As shown in other species, it is clear the importance of ethylene in the regulation of the changes in maturation and post-harvest life of apricot. The availability of inhibitors 
such as 1-MCP and AVG is very useful for understanding the mechanisms involved in the development of fruit quality traits. The results of this research allow for identifying which factors involved in flavor, such as changes in the levels of soluble solids and acidity, are not dependent on ethylene, at least during the postharvest stage. On the other hand, the effect of ethylene on the development of aroma is complex, presenting a direct effect on the changes observed in esters and aldehydes, and without any effect on the level of alcohols and terpenes. Other factors of quality such as color and firmness of the fruit were altered by the inhibition of ethylene, suggesting its participation as a regulator of processes that define both attributes. It is interesting to note that while ethylene significantly changed some of the attributes studied, this dependence was partial, having been modified by diverse factors, including the doses of the inhibitor used. This situation shows the complexity of the fruit maturation process, in which it is established that ethylene is only one factor among a great number.

\section{ACKNOWLEDGEMENTS}

This research was funded by FONDECYT Project 1060179.

Table 3. Volatile compounds (ng $\left.\mathrm{kg}^{-1}\right)$ in 'Modesto' apricots after 20 and 30 days of storage at $0^{\circ} \mathrm{C}$, plus a period at 20 ${ }^{\circ} \mathrm{C}$ to reach ripening.

\begin{tabular}{|c|c|c|c|c|c|c|c|}
\hline \multirow[b]{3}{*}{ Volatiles } & \multicolumn{7}{|c|}{ Storage time } \\
\hline & \multicolumn{4}{|c|}{20 days at $0^{\circ} \mathrm{C}$} & \multicolumn{3}{|c|}{20 days at $0^{\circ} \mathrm{C}+4$ days at $20^{\circ} \mathrm{C}$} \\
\hline & Harvest & Control & $\mathrm{AVG}^{3}$ & $1-\mathrm{MCP}^{4}$ & Control & AVG & 1-MCP \\
\hline Butyl butanoate & $0.2 \mathrm{~b}^{1}$ & $0.3 \mathrm{a}$ & $0.1 b$ & $0.1 b$ & $0.1 \mathrm{a}$ & $0.2 \mathrm{a}$ & $0.1 \mathrm{a}$ \\
\hline Ethyl octanoate & $0.5 \mathrm{a}$ & $0.7 \mathrm{a}$ & $0.2 \mathrm{~b}$ & $0.2 \mathrm{~b}$ & $0.3 \mathrm{a}$ & $0.3 \mathrm{a}$ & $0.9 \mathrm{a}$ \\
\hline Total esters & $0.7 \mathrm{a}$ & $1.0 \mathrm{a}$ & $0.3 \mathrm{~b}$ & $0.3 \mathrm{~b}$ & $0.4 \mathrm{a}$ & $0.5 \mathrm{a}$ & $1.0 \mathrm{a}$ \\
\hline Hexanal & $645.0 \mathrm{bc}$ & $885.0 \mathrm{ab}$ & $279.0 \mathrm{c}$ & $1146.0 \mathrm{a}$ & $284.0 \mathrm{a}$ & $194.0 \mathrm{a}$ & $178.0 \mathrm{a}$ \\
\hline T-2-hexenal & $466.0 \mathrm{a}$ & $443 \mathrm{a}$ & $204.0 \mathrm{~b}$ & $536.0 \mathrm{a}$ & $129.0 \mathrm{a}$ & $109.0 \mathrm{a}$ & $102.0 \mathrm{a}$ \\
\hline T-2-heptanal & $4.0 \mathrm{a}$ & $4.9 \mathrm{a}$ & $9.3 \mathrm{a}$ & $5.4 \mathrm{a}$ & $5.0 \mathrm{a}$ & $4.0 \mathrm{a}$ & $5.0 \mathrm{a}$ \\
\hline Hexyl acetate & $0.5 \mathrm{a}$ & $0.6 \mathrm{a}$ & $0.6 \mathrm{a}$ & $0.5 \mathrm{a}$ & $0.6 \mathrm{a}$ & $0.6 \mathrm{a}$ & $0.6 \mathrm{a}$ \\
\hline Total aldehydes & $1116.0 \mathrm{a}$ & $1334.0 \mathrm{a}$ & $493.0 \mathrm{a}$ & $1688.0 \mathrm{a}$ & $419.0 \mathrm{a}$ & $307.0 \mathrm{a}$ & $285.0 \mathrm{a}$ \\
\hline Linalool & $7.6 \mathrm{a}$ & $7.9 \mathrm{a}$ & $7.6 \mathrm{a}$ & $6.8 \mathrm{a}$ & $2.6 \mathrm{a}$ & $2.4 \mathrm{a}$ & $4.6 \mathrm{a}$ \\
\hline Total terpenes & $7.6 \mathrm{a}$ & $7.9 \mathrm{a}$ & $7.6 \mathrm{a}$ & $6.8 \mathrm{a}$ & $2.6 \mathrm{a}$ & $2.4 \mathrm{a}$ & $4.6 \mathrm{a}$ \\
\hline Hexyl alcohol & $\mathrm{ND}^{2}$ & ND & ND & ND & $20.8 \mathrm{a}$ & ND & $17.9 \mathrm{a}$ \\
\hline \multirow[t]{2}{*}{ Total alcohol } & ND & ND & ND & ND & $20.8 \mathrm{a}$ & ND & $17.9 \mathrm{a}$ \\
\hline & \multicolumn{4}{|c|}{30 days at $0^{\circ} \mathrm{C}$} & \multicolumn{3}{|c|}{30 days at $0^{\circ} \mathrm{C}+3$ days at $20^{\circ} \mathrm{C}$} \\
\hline Butyl butanoate & $0.2 \mathrm{a}$ & $0.3 \mathrm{a}$ & $0.2 \mathrm{a}$ & $0.2 \mathrm{a}$ & $0.2 \mathrm{a}$ & -5 & $0.2 \mathrm{a}$ \\
\hline Ethyl octanoate & $0.5 \mathrm{a}$ & $0.6 \mathrm{a}$ & $0.3 \mathrm{a}$ & $0.4 \mathrm{a}$ & $0.4 \mathrm{a}$ & - & $0.6 \mathrm{a}$ \\
\hline Total esters & $0.7 \mathrm{a}$ & $0.9 \mathrm{a}$ & $0.5 \mathrm{a}$ & $0.6 \mathrm{a}$ & $0.6 \mathrm{a}$ & - & $0.9 \mathrm{a}$ \\
\hline Hexanal & $645.0 \mathrm{a}$ & $371.0 \mathrm{~b}$ & $460.0 \mathrm{~b}$ & $217.0 \mathrm{c}$ & $776.0 \mathrm{a}$ & - & $413.0 \mathrm{~b}$ \\
\hline T-2-hexenal & $466.0 \mathrm{a}$ & $212.0 \mathrm{~b}$ & $250.0 \mathrm{~b}$ & $140.0 \mathrm{c}$ & $347.0 \mathrm{a}$ & - & $221.0 \mathrm{a}$ \\
\hline T-2-heptanal & $4.0 \mathrm{a}$ & $2.9 \mathrm{a}$ & $2.4 \mathrm{a}$ & $2.4 \mathrm{a}$ & $6.6 \mathrm{a}$ & - & $6.2 \mathrm{a}$ \\
\hline Hexyl acetate & $0.5 \mathrm{a}$ & $0.6 \mathrm{a}$ & $0.5 \mathrm{a}$ & $0.6 \mathrm{a}$ & $0.5 \mathrm{a}$ & - & $0.6 \mathrm{a}$ \\
\hline Total aldehydes & $1115.0 \mathrm{a}$ & $586.0 \mathrm{a}$ & $713.0 \mathrm{a}$ & $360.0 \mathrm{a}$ & $1130.0 \mathrm{a}$ & - & $641.0 \mathrm{a}$ \\
\hline Linalool & $7.6 \mathrm{a}$ & $6.6 \mathrm{a}$ & $5.7 \mathrm{a}$ & $9.2 \mathrm{a}$ & $5.9 \mathrm{a}$ & - & $9.8 \mathrm{a}$ \\
\hline Total terpenes & $7.6 \mathrm{a}$ & $6.6 \mathrm{a}$ & $5.7 \mathrm{a}$ & $9.2 \mathrm{a}$ & $5.9 \mathrm{a}$ & - & $9.8 \mathrm{a}$ \\
\hline Hexyl alcohol & $\mathrm{ND}$ & ND & $\mathrm{ND}$ & $\mathrm{ND}$ & $34.5 \mathrm{a}$ & - & $17.5 \mathrm{a}$ \\
\hline Total alcohol & ND & ND & ND & ND & $34.5 \mathrm{a}$ & - & $17.5 \mathrm{a}$ \\
\hline
\end{tabular}

${ }^{1}$ Different letters indicate significant differences among treatments for a compound according to the least significant difference test (LSD) ( $\left.p \leq 0.05\right)$. ${ }^{2} \mathrm{ND}$ : non-detectable levels. ${ }^{3} 1000 \mathrm{mg} \mathrm{L}{ }^{-1} \mathrm{AVG}$ (aminoethoxyvinylglycine). ${ }^{4} 10000 \mathrm{~nL} \mathrm{~L}^{-1}$ 1-MCP (1-methylcyclopropene). ${ }^{5}$ Fruits eliminated because of rot. 
Table 4. Volatile compounds (ng kg-1) in 'Patterson' apricots after 20 and 30 days of storage at $0{ }^{\circ} \mathrm{C}$, plus a period at 20 ${ }^{\circ} \mathrm{C}$ to reach ripening.

\begin{tabular}{|c|c|c|c|c|c|c|c|}
\hline \multirow[b]{3}{*}{ Volatiles } & \multicolumn{7}{|c|}{ Storage time } \\
\hline & \multicolumn{4}{|c|}{20 days at $0^{\circ} \mathrm{C}$} & \multicolumn{3}{|c|}{20 days at $0^{\circ} \mathrm{C}+4$ days at $20^{\circ} \mathrm{C}$} \\
\hline & Harvest & Control & $\mathbf{A V G}^{3}$ & $1-\mathrm{MCP}^{4}$ & Control & AVG & 1-МСР \\
\hline Butyl butanoate & $0.3 \mathrm{a}^{1}$ & $0.3 \mathrm{a}$ & $0.1 \mathrm{a}$ & $0.1 \mathrm{a}$ & $0.2 \mathrm{a}$ & $0.1 \mathrm{a}$ & $0.1 \mathrm{a}$ \\
\hline Ethyl octanoate & $2.6 \mathrm{a}$ & $3.5 \mathrm{a}$ & $1.8 \mathrm{a}$ & $1.7 \mathrm{a}$ & $1.1 \mathrm{a}$ & $1.8 \mathrm{a}$ & $0.7 \mathrm{~b}$ \\
\hline Total esters & $2.9 \mathrm{a}$ & $3.8 \mathrm{a}$ & $1.9 \mathrm{a}$ & $1.8 \mathrm{a}$ & $1.3 \mathrm{a}$ & $1.9 \mathrm{a}$ & $0.8 \mathrm{a}$ \\
\hline Hexanal & $734.0 \mathrm{a}$ & $232.0 \mathrm{~b}$ & $177.0 \mathrm{~b}$ & $444.0 \mathrm{ab}$ & $167.0 \mathrm{a}$ & $240.0 \mathrm{a}$ & $164.0 \mathrm{a}$ \\
\hline T-2-hexenal & $462.0 \mathrm{a}$ & $178.0 \mathrm{~b}$ & $164.0 \mathrm{~b}$ & $389.0 \mathrm{ab}$ & $81.0 \mathrm{~b}$ & $161.0 \mathrm{a}$ & $91.0 \mathrm{~b}$ \\
\hline T-2-heptanal & $5.1 \mathrm{a}$ & $4.6 \mathrm{a}$ & $5.4 \mathrm{a}$ & $5.4 \mathrm{a}$ & $4.0 \mathrm{a}$ & $5.7 \mathrm{a}$ & $10.0 \mathrm{a}$ \\
\hline Hexyl acetate & $0.8 \mathrm{a}$ & $0.7 \mathrm{a}$ & $0.6 \mathrm{a}$ & $0.7 \mathrm{a}$ & $0.6 \mathrm{a}$ & $0.7 \mathrm{a}$ & $0.4 \mathrm{a}$ \\
\hline Total aldehydes & $1202.0 \mathrm{a}$ & $415.0 \mathrm{~b}$ & $347.0 \mathrm{~b}$ & $839.0 \mathrm{~b}$ & $253.0 \mathrm{a}$ & $410.0 \mathrm{a}$ & $265.0 \mathrm{a}$ \\
\hline Linalool & $48.3 \mathrm{a}$ & $29.1 \mathrm{~b}$ & $31.0 \mathrm{~b}$ & $19.5 \mathrm{~b}$ & $18.9 \mathrm{ab}$ & $27.4 \mathrm{a}$ & $11.6 \mathrm{~b}$ \\
\hline Total terpenes & $48.3 \mathrm{a}$ & $29.1 \mathrm{~b}$ & $31.0 \mathrm{~b}$ & $19.5 \mathrm{~b}$ & $18.9 \mathrm{ab}$ & $27.4 \mathrm{a}$ & $11.6 \mathrm{~b}$ \\
\hline Hexyl alcohol & $19.8 \mathrm{a}$ & $3.8 \mathrm{a}$ & $2.7 \mathrm{a}$ & $7.4 \mathrm{a}$ & $12.1 \mathrm{a}$ & $4.3 \mathrm{a}$ & $16.7 \mathrm{a}$ \\
\hline \multirow[t]{2}{*}{ Total alcohol } & $19.8 \mathrm{a}$ & $3.8 \mathrm{a}$ & $2.7 \mathrm{a}$ & $7.4 \mathrm{a}$ & $12.1 \mathrm{a}$ & $4.3 \mathrm{a}$ & $16.7 \mathrm{a}$ \\
\hline & \multicolumn{4}{|c|}{30 days at $0^{\circ} \mathrm{C}$} & \multicolumn{3}{|c|}{30 days at $0^{\circ} \mathrm{C}+1$ days at $20^{\circ} \mathrm{C}$} \\
\hline Butyl butanoate & $0.3 \mathrm{a}$ & $0.2 \mathrm{a}$ & $0.2 \mathrm{a}$ & $0.3 \mathrm{a}$ & $0.3 \mathrm{a}$ & $0.2 \mathrm{a}$ & $0.1 \mathrm{a}$ \\
\hline Ethyl octanoate & $2.6 \mathrm{a}$ & $1.3 \mathrm{a}$ & $1.5 \mathrm{a}$ & $1.7 \mathrm{a}$ & $0.6 \mathrm{~b}$ & $2.1 \mathrm{a}$ & $0.5 \mathrm{~b}$ \\
\hline Total esters & $2.9 \mathrm{a}$ & $1.5 \mathrm{~b}$ & $1.7 \mathrm{ab}$ & $2.0 \mathrm{~b}$ & $0.9 \mathrm{a}$ & $2.3 \mathrm{a}$ & $0.6 \mathrm{a}$ \\
\hline Hexanal & $734.0 \mathrm{a}$ & $128.0 \mathrm{~b}$ & $182.0 \mathrm{~b}$ & $103.0 \mathrm{~b}$ & $117.0 \mathrm{a}$ & $216.0 \mathrm{a}$ & $259.0 \mathrm{a}$ \\
\hline T-2-hexenal & $462.0 \mathrm{a}$ & $120.0 \mathrm{~b}$ & $170.0 \mathrm{~b}$ & $84.0 \mathrm{~b}$ & $108.0 \mathrm{a}$ & $144.0 \mathrm{a}$ & $108.0 \mathrm{a}$ \\
\hline T-2-heptanal & $5.1 \mathrm{a}$ & $4.6 \mathrm{a}$ & $13.3 \mathrm{a}$ & $1.7 \mathrm{a}$ & $2.6 \mathrm{~b}$ & $12.3 \mathrm{a}$ & $5.8 \mathrm{~b}$ \\
\hline Hexyl acetate & $0.8 \mathrm{a}$ & $0.6 \mathrm{a}$ & $0.7 \mathrm{a}$ & $0.6 \mathrm{a}$ & $0.6 \mathrm{a}$ & $0.6 \mathrm{a}$ & $0.6 \mathrm{a}$ \\
\hline Total aldehydes & $1202.0 \mathrm{a}$ & $253.0 \mathrm{~b}$ & $365.0 \mathrm{~b}$ & $189.0 \mathrm{~b}$ & $229.0 \mathrm{a}$ & $373.0 \mathrm{a}$ & $373.0 \mathrm{a}$ \\
\hline Linalool & $48.3 \mathrm{a}$ & $5.5 \mathrm{~b}$ & $18.5 \mathrm{~b}$ & $12.1 \mathrm{~b}$ & $4.7 \mathrm{~b}$ & $20.0 \mathrm{a}$ & $8.7 \mathrm{ab}$ \\
\hline Total terpenes & $48.3 \mathrm{a}$ & $5.5 \mathrm{~b}$ & $18.5 \mathrm{~b}$ & $12.1 \mathrm{~b}$ & $4.7 \mathrm{~b}$ & $20.0 \mathrm{a}$ & $8.7 \mathrm{ab}$ \\
\hline Hexyl alcohol & $19.8 \mathrm{a}$ & $4.8 \mathrm{a}$ & $8.5 \mathrm{a}$ & $5.1 \mathrm{a}$ & $\mathrm{ND}^{2}$ & ND & $10.8 \mathrm{a}$ \\
\hline Total alcohol & $19.8 \mathrm{a}$ & $4.8 \mathrm{a}$ & $8.5 \mathrm{a}$ & $5.1 \mathrm{a}$ & ND & ND & $10.8 \mathrm{a}$ \\
\hline
\end{tabular}

${ }^{1}$ Different letters indicate significant differences among treatments for a compound according to the least significant difference test (LSD) ( $\left.\mathrm{p} \leq 0.05\right)$. ${ }^{2} \mathrm{ND}$ : non-detectable levels. ${ }^{3} 1000 \mathrm{mg} \mathrm{L}^{-1} \mathrm{AVG}$ (aminoethoxyvinylglycine). ${ }^{4} 10000 \mathrm{~nL} \mathrm{~L}^{-1} 1$-MCP (1-methylcyclopropene).

\section{RESUMEN}

Efecto de los inhibidores de etileno sobre atributos de calidad de damascos, variedades Modesto y Patterson durante almacenamiento. El damasco (Prunus armeniaca L.) es muy susceptible al ablandamiento de la pulpa, pérdida de sabor y pudriciones, especialmente durante postcosecha. Muchos de estos cambios que ocurren durante maduración son regulados por etileno. El objetivo del presente trabajo fue determinar el cambio de la calidad de damascos var. Modesto y Patterson tratados con 1-metilciclopropeno (1-MCP) y aminoetoxivinilglicina (AVG). Las dosis utilizadas fueron de 1000 y $10000 \mathrm{~nL} \mathrm{~L}^{-1}$ de 1-MCP (SmartFresh $\left.{ }^{\mathrm{TM}}\right), 100$ y $1000 \mathrm{mg} \mathrm{L}^{-1}$ de AVG (Retain ${ }^{\circledR} 15 \% \mathrm{p} / \mathrm{p}$ ) y su respectivo testigo. Las evaluaciones se realizaron tras 20 y 30 días de almacenamiento a $0{ }^{\circ} \mathrm{C}$ con su respectiva evaluación tras 3 a 4 días a $20^{\circ} \mathrm{C}$. En ambas variedades, los inhibidores de etileno aplicados tienen efecto en disminuir la tasa de producción de etileno respecto al testigo, especialmente para 'Patterson'. También se observó un efecto en la firmeza y retención de color de los frutos, presentando los tratamientos con inhibidores de etileno valores superiores respecto al testigo, por lo que estos parámetros serían dependientes de la producción de etileno. Para contenido de sólidos solubles y acidez titulable, no se obtuvieron resultados que puedan establecer diferencias entre frutos tratados y no tratados, por lo tanto se consideran 
etileno independientes. Los volátiles que presentaron una dependencia de la producción de etileno fueron los pertenecientes a los grupos de ésteres y aldehídos, no siendo el caso de los alcoholes y terpenos que no presentaron variaciones, lo que sugiere que el etileno no estaría involucrado en su síntesis.

Palabras clave: maduración, calidad, 1-metilciclopropeno, aminoetoxivinilglicina, Prunus armeniaca, aroma.

\section{LITERATURE CITED}

Abdi, N., W.B. McGlasson, P. Holford, M. Williams, and Y. Mizrahi. 1998. Response of climacteric and suppressed climacteric plums to treatment with propylene and 1-methylcyclopropene. Postharvest Biol. Technol. 14:29-39.

Abeles, F.B., P.W. Morgan, and M.E. Saltveit. 1992. Ethylene in plant biology. 414 p. $2^{\mathrm{a}}$ ed. Academic Press, San Diego, California, USA.

Adams, D.O., and S.F. Yang. 1979. Ethylene biosynthesis: identification of 1-aminocyclopropane-1-carboxylic acid as an intermediate in the conversion of methionine to ethylene. Proc. Natl. Acad. Sci. 76:170-174.

Aubert, C., and C. Chanforan. 2007. Postharvest changes in physicochemical properties and volatile constituents of apricot (Prunus armeniaca L.) characterization of 28 cultivars. J. Agric. Food Chem. 55:3074-3082.

Azondanlou, R., C. Darbellay, J.L. Luisier, J. Villettaz, and R. Amadó. 2003. Development of a model for quality assessment of tomatoes and apricots. Lebensm. Wiss. Tecnol. 36:223-233.

Balbontín, C., C. Gaete-Eastman, M. Vergara, R. Herrera, and M.A. Moya-Leon. 2007. Treatment with 1-MCP and the role of ethylene in aroma development of mountain papaya fruit. Postharvest Biol. Technol. 43: 67-77.

Baldwin, E. 2002. Fruit flavor, volatile metabolism and consumer perceptions. p. 89-106. In M. Knee (ed.) Fruit quality and its biological basis. CRC Press, Boca Raton, Florida, USA.

Bauchot, A.D., D.S. Mottram, A.T. Dodson, and P. John. 1998. Effect of aminocyclopropane-1-carboxylic acid oxidase antisense gene on the formation of volatile esters in cantaloupe Charentais melon (cv. Vedrandais). J. Agric. Food Chem. 46:4787-4792.

Blankenship, S.M., and J.M. Dole. 2003. 1Methylcyclopropene: a review. Postharvest Biol. Technol. 28:1-25.
Botondi, R., D. DeSantis, A. Bellicontro, K. Vizovitis, and F. Mencarelli. 2003. Influence of ethylene inhibition by 1-methylcyclopropene on apricot quality, volatile production, and glycosidase activity of low -and higharoma varieties of apricots. J. Agric. Food Chem. 51:1189-1200.

Bregoli, A.M., S. Scaramagli, G. Costa, E. Sabatini, V. Ziosi, S. Biondi, and P. Torrigiani. 2002. Peach (Prunus persica) fruit ripening: aminoethoxyvinilglycine (AVG) and exogenous polyamines affect ethylene emission and flesh firmness. Physiol. Plant. 114:472481.

Byers, R.E. 1997. Peach and nectarine fruit softening following aminoethoxyvinylglycine sprays and dips. HortScience 32:86-88.

Cardarelli, M., R. Botondi, K. Vizovitis, and F. Mencarelli. 2002. Effects of exogenous propylene on softening, glycosidase, pectinmethylesterase activity during postharvest ripening of apricots. J. Agric. Food Chem. 50:1441-1446.

Chahine, H., B. Gouble, J.M. Audergon, M. Souty, G. Albagnac, G. Jacquemin, et al. 1999. Effect of ethylene on certain quality parameters of apricot fruit (Prunus armeniaca L.) during maturation and postharvest evolution. Acta Hort. (ISHS) 488:577-584

De Martino, G., K. Vizovitis, R. Botondi, A. Bellincontro, and F. Mencarelli. 2006. 1-MCP controls ripening induced by impact injury on apricots by affecting SOD and POX activities. Postharvest Biol. Technol. 39:38-47.

Defilippi, B.G., A.M. Dandekar, and A.A. Kader. 2004. Impact of suppression of ethylene action or biosynthesis on flavor metabolites in apple (Malus domestica Borkh.) fruits. J. Agric. Food Chem. 52:5694-5701.

Dong, L., S. Lurie, and H-W Zhou. 2002. Effect of 1methylcyclopropene on ripening of 'Canino' apricots and 'Royal Zee' plums. Postharvest Biol. Technol. 24:135-145.

Dragovic-Uzelac, V., B. Levaj, V. Mrkic, D. Bursac, and M. Boras. 2007. The content of polyphenols and carotenoids in three apricot cultivars depending on stage of maturity and geographical region. Food Chem. 102:966-975.

Egea, M.I., M.C. Martínez-Madrid, P. Sánchez-Bel, M.A. Murcia, and F. Rojazo. 2007. The influence of electron-beam ionization on ethylene metabolism and quality parameters in apricot (Prunus armeniaca L., cv. Búlida). Food Sci. Technol. 40:1027-1035.

Fan, X., L. Argenta, and J.P. Mattheis. 2000. Inhibition of ethylene action by 1-methylcyclopropene prolongs storage life of apricots. Postharvest Biol. Technol. 20:135-142. 